\title{
PENINGKATKAN MOTIVASI BELAJAR MELALUI STRATEGI READING GUIDE KOLABORASI INDEX CARD MATCH DALAM PROSES PEMBELAJARAN PKn SISWA SMP
}

\author{
Oleh: \\ Ahmad Nasir Ari Bowo*, Novitasari* \\ Universitas Cokroaminoto Yogyakarta
}

\begin{abstract}
Abstrak
Tujuan penelitian ini adalah Untuk meningkatkan motivasi belajar Melalui Penerapan Strategi Reading Guide dikolaborasikan dengan Index Card Match dalam proses pembelajaran PKn pada siswa kelas VIII A SMP Negeri 5 Karanganyar Kabupaten Karanganyar tahun ajaran 2010/2011. Sebelum diberi tindakan motivasi siswa sangat kurang, meski guru telah memberikan pembelajaran tukar kartu namun belum berhasil. Solusi yang ditawarkan peneliti dalam penelitian ini adalah peneraan strategi pembelajaran Reading Guide dikolaborasikan dengan Index Card Match. Adapun yang menjadi subjek penelitian adalah guru kelas, kepala sekolah, seluruh siswa kelas VIII A SMP Negeri 5 Karanganyar Kabupaten Karanganyar yang berjumlah 40 dan peneliti itu sendiri. Data penelitian ini dikumpulkan melalui informen atau nara sumber, tempat dan peristiwa berlangsungnya aktifitas pembelajaran dan dokumen atau arsip. Pengumpulan data, penulis menggunakan beberapa metode yaitu: observasi, wawancara, dan angket. Prosedur dalam penelitian ini terdapat empat tahap yaitu perencanaan, pelaksanaan, pengamatan dan refleksi. Penelitian tindakan ini terdiri dari dua siklus. Penelitian tindakan ini diharapkan penerapan strategi pembelajaran Reading Guide dikolaborasikan dengan Index Card Match motivasi siswa dalam proses pembelajaran pada siswa kelas VIII A SMP Negeri 5 Karanganyar Kabupaten Karanganyar dapat meningkat minimal 75\% dari jumlah keseluruhan 40 siswa. Hasil penelitian ini menunjukkan bahwa tingkat Motivasi belajar siswa dalam proses pembelajaran PKn di kelas VIII A SMP Negeri 5 Karanganyar Kabupaten Karanganyar Tahun 2010/2011, yaitu dari siswa yang termotivasi, siwa yang memiliki dorongan untuk belajar, dan siswa yang senang mengikuti pembelajaran sebanyak 14 siswa (35\%). Setelah dilakukan tindakan yang disepakati yaitu melalui penerapan strategi Reading Guide dikolaborasikan dengan Index Card Match dalam proses pembelajaran PKn diperoleh hasil yaitu pada siklus I meningkat menjadi 27 siswa $(67,50 \%)$. Setelah dilakukan tindakan yang direvisi pada siklus II meningkat menjadi 35 siswa $(87,50 \%)$. Hasil penelitian ini sudah memenuhi indikator kinerja.
\end{abstract}

Kata Kunci: Strategi Reading Guide dikolaborasikan dengan Index Card Match, Motivasi Belajar, Siklus. 


\section{Pendahuluan}

Pendidikan adalah suatu proses dalam rangka mempengaruhi siswa agar dapat menyesuaikan diri sebaik mungkin terhadap lingkungannya dan dengan demikian akan menimbulkan perubahan dalam dirinya yang memungkinkannya untuk berfungsi secara adekuat dalam kehidupan masyarakat (Hamalik, 2003: 79). Berdasarkan pernyataan di atas maka pendidikan dapat diartikan sebagai suatu proses dimana guru memberikan pengetahuan kepada siswa untuk menuntun siswa agar dapat berkembang dalam lingkungan sekitar yang mengakibatkan suatu perubahan kearah yang lebih baik. Dalam pembelajaran diharapkan mencapai tujuan yang diinginkan yaitu perubahan tingkah laku siswa dari yang belum tau kearah yang lebih tau setelah pembelajaran berlangsung. Motivasi belajar merupa- kan salah satu kunci keberhasilan siswa. Dalam mengikuti pengajaran apabila memiliki motivasi yang tinggi maka akan tercapai tujuan pendidikan.

Motivasi belajar merupakan daya penggerak dari dalam maupun dari luar siswa yang menimbulkan kegiatan belajar dan memberikan arah pada kegiatan belajar, sehingga dapat mencapai tujuan yang diharapkan. Motivasi dari luar dipengaruhi oleh lingkungan sekitar, sedang motivasi dari dalam dipengaruhi oleh diri seseorang itu sendiri. Untuk meningkatkan sebuah motivasi dibutuhkan semangat serta dorongan yang tinggi untuk melakukan sesuatu hal. Masalah dalam pendidikan khususnya masalah dalam kelas sering terjadi dan menjadi penghambat dalam proses pembelajaran. Dalam pembelajaran secara nyata sering dijumpai beberapa siswa yang memiliki masalah malas dalam mengikuti proses pengajaran. Siswa yang malas mengikuti pelajaran cenderung mendapat nilai di bawah rata-rata. Untuk mengubah sikap siswa tersebut harus melalui sebuah proses yaitu proses dimana guru mampu mempengaruhi siswanya untuk menerima rangsangan melalui pelajaran yang diberikan. Permasalahan dalam kelas sering terjadi di sekolah manapun, namun yang berbeda adalah tingkat permasalahannya. Di sini akan dibahas permasalahan yang terjadi pada siswa kelas VIII A SMP Negeri 5 Karanganyar Kabupaten Karanganyar. Berdasarkan hasil wawancara dan observasi pada tanggal 17 Maret 2011 membuktikan bahwa siswa di kelas ini pada dasarnya memiliki potensi yang lebih apabila dapat diarahkan secara baik. Rendahnya motivasi belajar membuat siswa malas dalam mengikuti pembelajaran. Ketika guru memberikan pertanyaan hanya beberapa siswa yang mau menjawab, sedang siswa yang lain hanya bermalas-malasan dan tidak mau memperhatikan. Dari 40 siswa kelas VIII A hanya 14 siswa yang memiliki tingkat motivasi belajar tinggi. Ketika guru 
memberikan tugas untuk mengerjakan soal siswa yang malas tidak segera mengerjakan. Ada siswa yang hanya tiduran di atas meja, ada siswa yang berbicara sendiri dengan temannya, dan ada juga yang bersandar di dinding. Permasalahan tersebut sering terjadi di kelas VIII A ketika proses pembelajaran Pendidikan Kewarganegaraan berlangsung. Untuk mengatasi masalah tersebut Dra. Prabaningrum selaku guru Pendidikan Kewarganegaraan telah mencoba menggunakan strategi tukar kartu, selain itu guru juga telah memberikan motivasi kepada siswanya agar lebih giat belajar namun hal tersebut dirasa belum berhasil karena siswa masih belum termotivasi untuk belajar.

Masalah pendidikan di atas khususnya masalah dalam proses pembelajaran penting untuk kita selesaikan secara bersama. Kerja sama dari semua pihak diharapkan dapat memecahkan masalah tersebut. Untuk mengatasi masalah di atas maka dalam penelitian tindakan kelas ini akan diterapkan strategi Reading Guide yang dikolaborasikan dengan Index Card Match. Dengan strategi tersebut siswa akan lebih senang dan memiliki motivasi untuk mengikuti pembelajaran, karena dalam strategi tersebut akan diterapkan pembelajaran yang menarik dan menyenangkan. Pada umumnya siswa di sini lebih suka bermain, oleh karena itu diterapkan pembelajaran dengan cara belajar sambil bermain. Sebelum siswa belajar dengan bermain siswa diberikan bekal supaya dapat meningkatkan semangat untuk belajar. Diharapkan strategi tersebut dapat meningkatkan rendahnya motivasi belajar siswa dalam proses pembelajaran PKn.

Dari uraian di atas maka penting untuk mengadakan penelitian mengenai " Upaya Meningkatkan Motivasi Belajar Melalui Penerapan Strategi Reading Guide Dikolaborasikan dengan Index Card Match Dalam Proses Pembelajaran PKn Pada siswa Kelas VIII A SMP Negeri 5 Karanganyar Kabupaten Karanganyar Tahun Ajaran 2010/2011”.

\section{Kajian Teori}

\section{Kajian Mengenai Strategi Reading Guide}

Pengertian Strategi Reading Guide. Pengertian strategi Reading Guide menurut Bariroh, Metode Reading Guide adalah Strategi yang memandu peserta didik untuk membaca panduan yang disiapkan oleh guru sesuai dengan materi yang akan diajarkan dengan waktu yang sudah ditentukan, disisi lain guru juga akan memberi pertanyaan yang membahas seputar materi yang telah dibaca oleh peserta didik setelah kegiatan membaca tersebut dengan panduan bacaan yang telah diberikan guru tersebut. 
Langkah-Langkah Pelaksanaan Strategi Reading Guide. Menurut Zaini dkk. (2008:8-

9) langkah-langkah pelaksanaan strategi Reading Guide antara lain:

1) Tentukan bacaan yang dipelajari.

2) Buat pertanyaan-pertanyaan yang akan dijawab oleh peserta didik atau kisi-kisi dan boleh juga bagan atau skema yang dapat diisi oleh mereka dari bahan bacaan yang telah dipilih tadi.

3) Bagikan bahan bacaan dengan pertanyaan atau kisi-kisinya kepada peserta didik.

4) Tugas peserta didik adalah mempelajari bahan bacaan dengan menggu- nakan pertanyaan atau kisi-kisi yang ada. Batasi aktifitas ini sehingga tidak akan memakan waktu yang berlebihan.

5) Bahas pertanyaan atau kisi-kisi tersebut dengan menanyakan jawabannya kepada peserta didik.

6) Di akhir pelajaran beri ulasan secukupnya.

\section{Kajian Mengenai Strategi Index Card Match}

Pengertian Strategi Index Card Match. Menurut Zaini dkk. (2008:67) “ Index Card Match (mencari pasangan) adalah strategi yang cukup menyenangkan yang digunakan untuk mengulang materi yang telah diberikan sebelumnya". Selanjutnya untuk memperjelas pemahaman mengenai strategi Index Card Match dapat dijelaskan bahwa: Strategi pembelajaran Index Card Match adalah strategi pembelajaran yang menuntut siswa untuk bekerja sama serta meningkatkan rasa tanggung jawab siswa atas apa yang dipelajari dengan cara yang menyenangkan.

Langkah-Langkah Pelaksanaan Strategi Index Card Match. Menurut Zaini dkk. (2008:67-68) langkah-langkah strategi Index Card Match (mencari pasangan) yaitu:

1) Buatlah potongan-potongan kertas sejumlah peserta didik yang ada dalam kelas.

2) Bagi jumlah kertas-kertas tersebut menjadi dua bagian yang sama.

3) Tulis pertanyaan tentang materi yang telah diberikan sebelumnya pada setengah bagian kertas yang telah disiapkan. Setiap kertas berisi satu pertanyaan.

4) Pada separo kertas yang lain, tulis jawaban dari pertanyaan-pertanyaan yang tadi dibuat.

5) Kocoklah semua kertas sehingga akan tercampur antar soal dan jawaban. 
6) Beri setiap peserta didik satu kertas. Jelaskan bahwa ini adalah aktivitas yang dilakukan berpasangan. Separo peserta didik akan mendapatkan soal dan separo yang lain akan memdapatkan jawaban.

7) Minta peserta didik untuk menemukan pasangan mereka. Jika ada yang sudah menemukan pasangan, minta mereka untuk duduk berdekatan. Terangkan juga agar mereka tidak memberitahukan materi yang mereka dapatkan kepada teman yang lain.

8) Setelah semua peserta didik menemukan pasangan dan duduk berdekatan, minta setiap pasangan secara bergantian untuk membacakan soal yang diperoleh dengan keras kepada teman-teman yang lain. Selanjutnya soal tersebut dijawab oleh pasangan-pasangan yang lain.

9) Akhiri proses ini dengan membuat klarifikasi dan kesimpulan.

\section{Kajian Mengenai Kolaborasi Strategi Reading Guide dengan Index Card Match}

Pengertian Kolaborasi. Pengertian mengenai kolaborasi dapat diperoleh dari berbagai sumber salah satunya dari Kamus Besar Bahasa Indonesia (2008: 580) "Kolaborasi (perbuatan) adalah kerja sama dengan musuh." Selanjutnya menurut Madya (2007:51) "penelitian tindakan yang sejati adalah penelitian tindakan kolaboratif, yaitu yang dilakukan oleh sekelompok peneliti melalui kerja sama dan bekerja bersama".

Lngkah-Langkah Pelaksanaan Strategi Kolaborasi Reading Guide dengan Index Card Match. Langkah-langkah pelaksanaan strategi pembelajaran kolaborasi Reading Guide dengan Index Card Match antara lain:

1) Tentukan bacaan yang dipelajari.

2) Buat kisi-kisi yang akan digunakan untuk menjawab pertanyaan dalam mencari pasangan.

3) Bagikan bahan bacaan dengan kisi-kisinya kepada peserta didik.

4) Tugas peserta didik adalah mempelajari bahan bacaan dengan menggunakan kisi-kisi yang ada. Batasi aktifitas ini sehingga tidak akan memakan waktu yang berlebihan.

5) Buatlah potongan-potongan kertas sejumlah peserta didik yang ada dalam kelas.

6) Bagi jumlah kertas-kertas tersebut menjadi dua bagian yang sama.

7) Tulis pertanyaan tentang materi yang telah diberikan sebelumnya pada setengah bagian kertas yang telah disiapkan. Setiap kertas berisi satu pertanyaan.

8) Pada separo kertas yang lain, tulis jawaban dari pertanyaan-pertanyaan yang tadi dibuat.

9) Kocoklah semua kertas sehingga akan tercampur antar soal dan jawaban. 
10) Beri setiap peserta didik satu kertas. Jelaskan bahwa ini adalah aktivitas yang dilakukan berpasangan. Separo peserta didik akan mendapatkan soal dan separo yang lain akan memdapatkan jawaban.

11) Minta peserta didik untuk menemukan pasangan mereka. Jika ada yang sudah menemukan pasangan, minta mereka untuk duduk berdekatan. Terangkan juga agar mereka tidak memberitahukan materi yang mereka dapatkan kepada teman yang lain.

12) Setelah semua peserta didik menemukan pasangan dan duduk berdekatan, minta setiap pasangan secara bergantian untuk membacakan soal yang diperoleh dengan keras kepada teman-teman yang lain. Selanjutnya soal tersebut dijawab oleh pasangan-pasangan yang lain.

13) Akhiri proses ini dengan membuat klarifikasi dan kesimpulan.

\section{Metode Penelitian}

Tempat penelitian ini adalah di SMP Negeri 5 Karanganyar Kabupaten Karanganyar Tahun Ajaran 2010/2011. Tahap-tahap pelaksanaan kegiatan sejak persiapan sampai dengan penulisan laporan penelitian secara keseluruhan dilakukan selama kurang lebih empat bulan, yaitu sejak bulan maret sampai bulan juni 2011. Berbagai pengertian mengenai subjek penelitian telah dikemukakan oleh para ahli. Menurut Suwandi (2009:55) "Subjek penelitian adalah siswa dan guru yang terlibat dalam pelaksanaan pembelajaran". Subjek penelitian tergantung pada setting penelitian dan peneliti. Subjek dalam penelitian ini antara lain:

1. Guru PKn kelas VIII A SMP Negeri 5 Karanganyar Kabupaten Karanganyar yaitu bertindak sebagai subjek yang memberikan tindakan.

2. Kepala sekolah SMP Negeri 5 Karanganyar Kabupaten Karanganyar Tahun Ajaran 2010/2011 sebagai subjek yang membantu dalam memberikan izin dalam penelitian ini.

3. Seluruh siswa kelas VIII A SMP Negeri 5 Karanganyar Kabupaten Karanganyar sebagai subjek penelitian yang menerima tindakan.

Peneliti sebagai subjek yang bertugas merencanakan, mengumpulkan data, menganalisis data, dan membuat kesimpulan penelitian. Ada beberapa ahli yang mengemukakan model penelitian tindakan kelas diantaranya, menurut Arikunto dkk. (2006:16) "model penelitian tindakan kelas secara garis besar terdapat empat tahapan yang harus dilalui, yaitu (1) perencanaan, (2) pelaksanaan, (3) pengamatan, (4) refleksi”. 
Penelitian tindakan kelas ini menggunakan jenis data kualitatif, yaitu data yang berbentuk kata, kalimat, skema dan gambar. Menurut Sugiyono (2010:14) "Data kualitatif adalah data yang berbentuk kata, kalimat, skema dan gambar". Menurut Arikunto (2006:129) "sumber data dalam penelitian adalah subjek dari mana dan dapat diperoleh". Data yang dikumpulkan dalam penelitian ini adalah tentang motivasi belajar dalam proses pembelajaran di kelas. Data penelitian ini dikumpulkan dari berbagai sumber yaitu:

1. Informasi atau narasumber, yaitu dari guru dan siswa kelas VIII A SMP Negeri 5 Karangnayar Kabupaten Karanganyar.

2. Tempat dan peristiwa berlangsungnya proses pembelajaran Pendidikan Kewarganegaraan. Lokasi penelitian adalah SMP Negeri 5 Karanganyar Kabupaten Karanganyar.

\section{Hasil Penelitian dan Pembahasan}

Pembahasan terhadap permasalahn penelitian maupun hipotesis tindakan berdasarkan analisis data kualitatif, dari hasil penelitian kolaboratif antara peneliti dan observer serta tanggapan guru PKn yang terlibat dalam kegiatan ini, serta profil kelas sebelum dan sesudah penelitian yang dibuat oleh peneliti yang melakukan tindakan kolaborasi dimulai dari: (1) perencanaan tindakan, (2) pelaksanaan tindakan, (3) pengamatan tindakan, (4) refleksi hasilnya sebagai berikut, tentang proses pembelajaran dengan strategi pembelajaran Reading Guide dikolaborasikan dengan Index Cart Match dan hasil penelitian yang dilakukan secara kolaboratif antara peneliti, observer, guru kelas dan kepala sekolah menyatakan bahwa dalam proses pembelajaran PKn dengan mengguna- kan strategi pembelajaran Reading Guide dikolaborasikan dengan Index Card Match telah memberikan dorongan kepada guru untuk mengembangkan strategi pembelajaran baru yang inovatif.

Pembelajaran dengan strategi Reading Guide dikolaborasikan dengan Index Card Match merupakan pembelajaran dimana siswa harus ikut berperan dalam kegiatan pembelajaran, dimana siswa dapat belajar sambil bermain sehingga menumbuhkan rasa senang pada suatu pelajaran. Dengan strategi Reading Guide dikolaborasikan dengan Index Card Match telah mampu meningkatkan motivasi belajar siswa dalam mengikuti pembelajaran PKn pada tiap tindakan siklus yang dilaksanakan oleh peneliti. Siswa menjadi bersemangat dalam belajar, sehingga proses belajar mengajar berjalan dengan lancar. 
Strategi Reading Guide dikolaborasikan dengan Index Card Match dapat meningkatkan semangat dan daya juang siswa dalam prose pembelajaran PKn. Guru kelas VIII A telah melakukan suatu perbaikan dalam pembelajaran. Perbaikan tindakan tersebut adalah memberikan motivasi yang tinggi pada siswa. Motivasi belajar sebelum tindakan penelitian hanya sebesar $35 \%$ sesuai dengan indikator motivasi belajar. Selanjutnya peneliti menerapkan strategi baru yaitu penggunaan strategi Reading Guide dikolaborasikan dengan Index Card Match, partisipasi siswa sebelum pelaksanaan siklus I diketahui motivasi belajar siswa sebesar 63,33\%. Pada penerapan siklus I motivasi belajar siswa yang sesuai dengan indikator motivasi belajar meningkat sebesar $66,04 \%$. Kemudian peneliti mengadakan revisi dan evaluasi untuk dilanjutkan pada siklus II, dimana pada siklus II motivasi belajar siswa meningkat sebesar $80,41 \%$ sesuai dengan indikator motivasi belajar. Pada saat proses pembelajaran berlangsung, tiap siklus mengalami peningkatan yang optimal yang sesuai dengan indikator. Pada awal siklus I hasil peningkatan belum sesuai harapan. Setelah siklus berikutnya yaitu siklus II berjalan dengan baik mengalami peningkatan sesuai harapan. Hasil yang dicapai dalam siklus II motivasi belajar siswa sudah sesuai dengan indikator motivasi belajar. Gambar di bawah adalah grafik perkembangan penerapan strategi Reading Guide dikolaborasikan dengan Index Card Match dalam upaya meningkatkan motivasi belajar siswa mulai dari kondisi awal sampai pada tindakan pada siklus II.

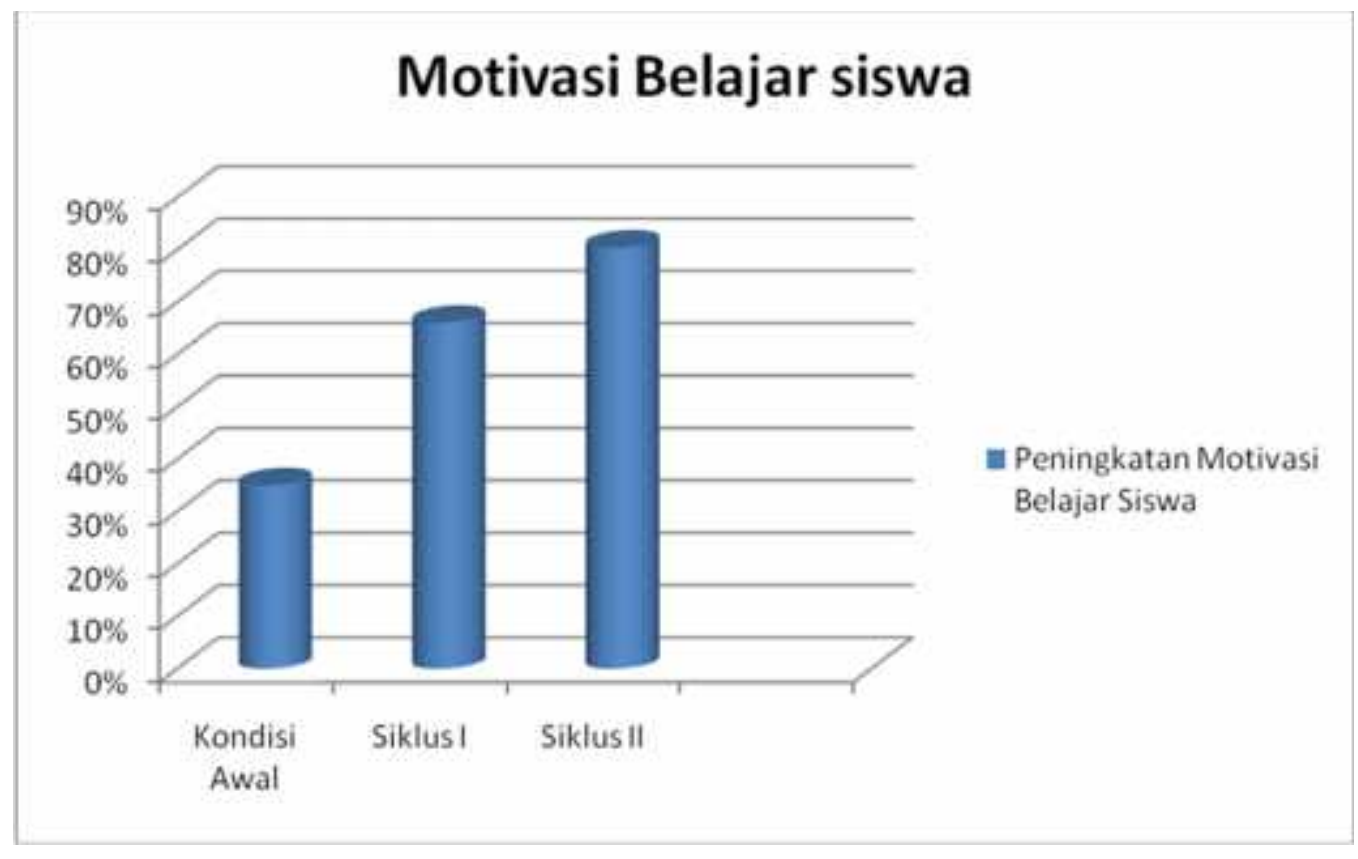

Gambar 1. Perkembangan Peningkatan Motivasi Belajar Siswa 


\section{Keterangan:}

1. Motivasi belajar siswa pada saat kondisi awal sebesar $35 \%$.

2. Motivasi belajar siswa pada saat siklus I sebesar $66,04 \%$.

3. Motivasi belajar siswa pada saat siklus II sebesar $80,41 \%$.

Berdasarkan penelitian yang dilakukan, peneliti dapat mengetahui kelebihan dan kekurangan pembelajaran dengan menggunakan strategi Reading Guide dikolaborasikan dengan Index Card Match yaitu sebagai berikut:

\section{Kelebihan}

a. Dapat digunakan untuk inovasi pembelajaran.

b. Dapat digunakan untuk mengembangkan kurikulum di tingkat kelas.

c. Dapat digunakan untuk meningkatkan profesionalisme guru.

d. Menambah pengetahuan guru dalam mendapatkan strategi pembelajaran baru.

e. Siswa lebih mudah memahami pelajaran karena siswa terlibat langsung dalam pembelajaran

f. Siswa lebih tertarik mengikuti pelajaran karena menggunakan strategi Reading Guide dikolaborasikan dengan Index Card Match.

g. Pembelajaran dengan strategi Reading Guide dikolaborasikan dengan Index Card Match membuat siswa lebih bersemangat.

\section{Kekurangan}

a. Dalam pembelajaran dengan strategi Reading Guide dikolaborasikan dengan Index Card Match ini guru perlu membuat media yang menarik untuk memudahkan siswa dalam memahami materi pelajaran PKn.

b. Dibutuhkan ruang kelas yang memadai agar pembelajaran dapat berjalan dengan lancar.

c. Dibutuhkan pengelolaan kelas yang baik demi tercapainya tujuan yang diharapkan.

d. Guru harus bisa mengkondisikan kelas dengan baik agar tidak meng- ganggu kelas lain, karena siswa akan sangat ramai ketika proses pem- belajaran berlangsung. 


\section{Kesimpulan}

Dari rangkaian putaran penelitian tindakan kelas yang telah dilakukan oleh peneliti terlihat adanya perubahan yang merupakan hasil penelitian dalam rangka usaha meningkatkan motivasi belajar siswa, siswa yang bersemangat mengikuti pelajaran $\mathrm{PKn}$, mengerjakan tugatugas dari guru. Dari penelitian yang telah dilakukan memberi kesimpulan sebagai berikut:

1. Adanya peningkatan motivasi belajar siswa dalam proses pembelajaran sesuai dengan indikator yang telah ditetapkan sebesar $80,41 \%$.

2. Motivasi belajar siswa dalam proses pembelajaran sesuai dengan indikator yang telah ditetapkan sebelum tindakan sebesar 35\%. Pada siklus I sebesar 66,04\% dan pada siklus II sebesar $80,41 \%$.

\section{Daftar Pustaka}

Arikunto, Suharsimi. 2006. Prosedur Penelitian Suatu Pendekatan Praktik. Jakarta: Rineka Cipta.

Arikunto, Suharsimi dkk. 2006. Penelitian Tindakan Kelas. Jakarta: Bumi Aksara.

Aunurrahman. 2009. Belajar dan Pembelajaran. Bandung: Alfabeta.

Hadi, Sutrisno. 1989. Metodologi Research jilid II. Yogyakarta: Andi Offset.

Hamalik, Oemar.1995. Kurikulum dan Pembelajaran. Jakarta: Bumi Aksara.

Hamalik, Oemar. 2003. Proses Belajar Mengajar. Jakarta: Bumi Aksara.

Jogiyanto. 2006. Filosofi, Pendekatan, dan Penerapan Pembelajaran Metode Kasus. Yogyakarta: Andi Offset.

Madya, Suwarsih. 2007. Teori dan Praktik Penelitian Tindakan (Action Research). Bandung: Alfabeta.

Milles, Matthew B. dan A. Michael Hubberman. 1992. Analisis Data Kualitattif: Buku Sumber Tentang Metode-metode Baru. Jakarta: UI Press.

Muashomah, Binti Faridatul. 2009. "Penerapan Strategi Reading Guide dan Index Card Match Untuk Meningkatkan Motivasi Belajar Tentang Akhlak Terpuji Pada Siswa Kelas V Madrasah Ibtidaiyah Negeri Cengkok Ngronggot Nganjuk". Skripsi Jurusan Pendidikan Guru Madrasah Ibtidaiyah Fakultas Tarbiyah. Malang: Universitas Islam Negeri (http://lib.uin-malang.ac.id/ abstract /07140050.pdf). Diakses Rabu, 23 Maret 2011 Pukul 15.05 WIB. 
Moleong, Lexy J. 1991. Metodologi Penelitian Kualitatif. Bandung: Remaja Rosdakarya.

Nasution. 2001. Metode Research (Penelitian Ilmiah). Jakarta: Bumi Aksara.

Nawawi, Hadari dan Martini Hadawi. 1992. Instumen Penelitian Bidang Sosial. Yogyakarta: Gajah Mada University Press.

Nazir, Mohammad. 1988. Metode Penelitian. Jakarta: Ghalia Indonesia.

Prawiradilaga, Dewi Salma. 2008. Prinsip Desain Pembelajaran. Jakarta: Kencana.

Pusat Bahasa Departemen Pendidikan Nasional. 2005. Kamus Besar Bahasa Indonesia Edisi Ketiga. Jakarta: Balai Pustaka.

Ratna, Nyoman Kutha. 2010. Metodologi Penelitan Kajian Budaya dan Ilmu Sosial Humaniora pada Umumnya. Yogyakarta: Pustaka Pelajar.

Sardiman. 1996. Interaksi dan Motivasi Belajar Mengajar Pedoman Bagi Guru dan Calon Guru. Jakarta: Raja Grafindo Persada.

Sugiyono. 2006. Metode Penelitian Kuantitatif, Kualitatif dan R\&B. Bandung: Alfabeta.

Sugiyono. 2010. Metode Penelitian Adminstrasi Dilengkapi dengan Metode R\&B. Bandung: Alfabeta.

Suwandi, Sarwiji. 2009. Penelitian Tindakan Kelas (PTK) dan Penulisan Karya Tulis Ilmiah. Surakarta: Panitia Sertifikasi Guru Rayon 13 FKIP UNS.

Suyanto. "Implementasi Pembelajaran Kooperatif dengan Index Card Match untuk Meningkatkan Motivasi dan Hasil Belajar IPS Siswa Kelas V SD Negeri 02 Wukir Sawit Jatiyoso Kabupaten Karanganyar 2009/2010”. Skripsi. Program S-1 Pendidikan Guru Sekolah Dasar FKIP. Surakarta: Universitas Muhammadiyah Surakarta.

Uno, Hamzah B. 2008. Teori Motivasi dan Pengukurannya Analisis di Bidang Pendidikan. Jakarta: Bumi Aksara.

Wlodkowski, Raymond J. dan Judith H. Jaynes. 2004. Hasrat Untuk Belajar=Eager to Learn Membantu Anak-anak Termotivasi dan Mencintai Belajar. Yogyakarta: Pustaka Pelajar.

Zaini, Hisyam dkk. 2008. Strategi Pembelajaran Aktif. Yogyakarta: Insan Madani. 